\title{
EL REY FUNDADOR: JAIME I \\ EN LA ICONOGRAFÍA MERCEDARIA
}

\author{
THE FOUNDING KING: JAIME I IN THE \\ ICONOGRAPHY OF THE MERCEDARIAN ORDER
}

Vicent Francesc Zuriaga Senent

Universidad Católica de Valencia

Recibido: 26/09/2019. Evaluado: 13/10/2019. Aprobado: 03/11/2019.

RESUMEN: La construcción de la imagen devocional del rey Jaime I tiene su origen en el retrato de la fama que de él relatan las crónicas. Esta imagen devocional se va consolidando paulatinamente en los escritos y obras de arte de los siglos XIV al xVII. En este trabajo se estudia y se analiza cómo se impulsa la apoteosis de su imagen como rey fundador gracias al interés de la Orden de la Merced por vincular su origen fundacional con la monarquía, así como por parte de la casa de los Austrias por elevar a los altares a un rey de su linaje.

Palabras clave: Jaime I, Orden de la Merced, rey fundador, canonización, iconografía.

ABSTRACT: The construction of the devotional image of King Jaime I has its origin in the portrait of fame that may be found in the chronicles. This devotional image gradually consolidates in the written texts and works of art produced in the $14^{\text {th }}$ century up to the $18^{\text {th }}$ century. The main aim of this work is to study and analyze how the apotheosis of his image as a founding king is promoted on the one hand by the Order of Mercy, who was interested in linking his foundational origin with the 
monarchy, and on the other by the house of the Habsburgs, who wanted to raise a king of their lineage to the altars.

Keywords: Jaime I, Order of Mercy, founding king, canonization, iconography

\section{INTRODUCCIÓN}

En enero de 2018, se iniciaron en Roma las celebraciones del año jubilar de la Orden de la Merced con motivo del $800 .^{\circ}$ aniversario de su fundación. ${ }^{1} \mathrm{La}$ basílica vaticana acogió a los pies de la imagen de san Pedro Nolasco la misa en acción de gracias. Los mercedarios eligieron como imagen representativa para ilustrar el libreto de la ceremonia de este aniversario el grabado de Pedro Perret Institoris navis donde aparece Jaime I como fundador de la orden portando el estandarte con el escudo mercedario.

Las crónicas mercedarias y las de los dominicos presentan como cofundadores de la Merced al rey Jaime I, a san Raimundo de Peñafort y a san Pedro Nolasco (fig. 1). Sin embargo, no coinciden en las fechas. Los dominicos retrasan la fundación de la Merced hasta 1223, año de regreso de san Raimundo a Barcelona después de haber cursado estudios en Bolonia entre 1217 y $1222 .{ }^{2}$ Los mercedarios afirman la presencia de Raimundo de Peñafort en Barcelona en 1218, año en que es nombrado canónigo de la catedral por el obispo Berenguer de Palou. ${ }^{3}$

En lo que sí coinciden las crónicas mercedarias y dominicas es en el papel de Jaime I como fundador de la orden y en la labor legislativa de san Raimundo (que en 1222 había ingresado en la Orden de Predicadores) en la redacción del decreto de Gregorio IX de 1235 que traza el inicio del itinerario jurídico por el que los mercedarios se someten a la regla de san Agustín como carisma de la nueva institución.

Resulta paradójico que ni el propio rey en el Llibre dels feits ni las crónicas de Bernat Desclot o Ramón Muntaner, relaten la participación del monarca en la fundación de la Orden de la Merced. Además, cabe recordar que, nacido en 1210, el rey apenas tendría ocho años en 1218, por lo que las fechas de las cró-

1. El presente artículo se enmarca dentro de los proyectos de investigación HAR2015-65176-P del Grupo Apes de la Universitat de València y los proyectos del Grupo Humanidades Digitales de la Universidad Católica de Valencia.

2. Ramón Dilla Martí: Sant Ramon de Penyafort. Imatge, devoció i santedat. Tesis doctoral publicada por la Universitat de Barcelona, 2017, p. 26. http://hdl.handle.net/10803/418807 (consultada el 17 de julio 2019).

3. James William Bordman: «New Perspectives on the Creation of the Mercedarian Order», en M. a Teresa Ferrer Mallol (ed.): Jaume I. Conmemoració del VIII centenari del naixement, Institut d'estudis Catalans, Barcelona, 2013, vol II., pp, 389-401. Este artículo de Bordman resulta muy interesante, pues revisa sus tesis sobre la fundación de la orden de la Merced realizadas en 1985. 
nicas mercedarias presentan algunos interrogantes. Esta polémica circunstancia ha sido utilizada por varios autores ${ }^{4}$ para dudar de la vinculación del rey Jaime I como determinante en la fundación y como prueba suficiente para cuestionar el relato defendido por las crónicas mercedarias. ${ }^{5}$ Sin embargo, en 1325, Ramón Muntaner, en el capítulo xxiıI de su crónica, indica que Jaime I en su viaje al Concilio de Lion desde Valencia se detiene a visitar a la Madona Sancta Maria del Puig en su primera etapa de viaje. Esta visita expresa una devoción particular del rey a la que según la tradición es, desde el año de la conquista, patrona del Reino de Valencia conforme a los relatos del prodigioso hallazgo de la imagen por parte de Nolasco y el rey, y su consecuente relación con la fundación del monasterio mercedario del Puig, donde se venera la imagen según afirman las crónicas de los siglos XV, XVI y XVII.

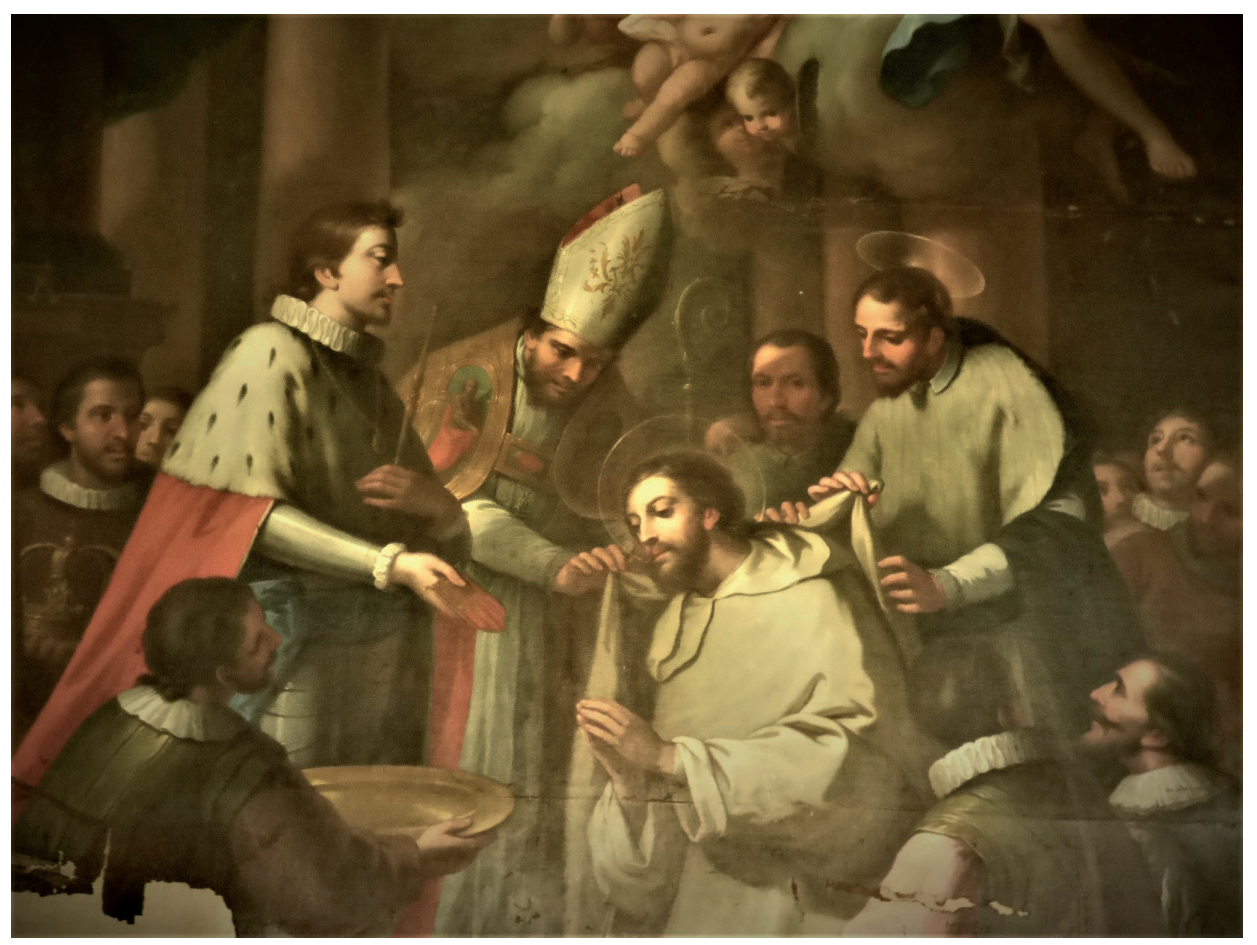

Fig. 1. José Vergara, Fundación de la Orden de la Merced por el rey Jaime I, siglo XVIII, Monasterio del Puig, Valencia

4. En este aspecto cabe destacar las publicaciones de Bordman y Taylor: J. W. BrodMAN: Ransoming Captives in Crusader Spain: The Order of Merced on the ChristianIslamic Frontier, Filadelfia, 1986 (traducción catalana, Barcelona, 1990, p. 53). BRUCE TAYLOR: «La Orden de la Merced en crisis: un aspecto de la historia eclesiástica franco-catalana de los siglos XVI-XVII», en Pedralbes, Revista d'Història Moderna, Actes del IV Congrés d'Història Modèrna de Catalunya, Barcelona, 1998, p. 557.

5. Vicent F. Zuriaga Senent: La imagen devocional en la Orden de Nuestra Señora de la Merced: tradición, formación, continuidad y variantes, Universitat de Valencia. 2005. Institució Alfons el Magnánim, Valencia, 2008, p. 34. 
Si bien el Llibre dels feits no refiere la participación de Jaime I en la fundación de la Merced, la relación del rey con la orden está documentada en otros escritos. Aparte de las donaciones reales descritas en El repartiment de Mallorca y Valencia, en el Archivo de la Corona de Aragón se conservan veintiún ${ }^{6}$ documentos del rey Jaime I en relación con la Orden de la Merced. ${ }^{7}$

De esta vinculación con Jaime I, por la participación de Nolasco en las campañas militares, surgirán las donaciones y privilegios reales documentados por Gazulla, ${ }^{8}$ entre otros origen del convento de Santa Eulalia en Barcelona, las donaciones en El repartiment de Mallorca de 1235; las consignadas en el Llibre del repartiment de Valencia, asientos de 14 de julio y 16 de septiembre de 1238, así como las fundaciones de conventos en la provincia mercedaria de Aragón durante su reinado. Burns ${ }^{9}$ sitúa la fundación de la Orden de la Merced en Barcelona en los años anteriores a la construcción del primer establecimiento mercedario erigido frente al mar en el solar donado en 1232 por Ramón Plegamans, comandante de la flota con la que Jaime I conquistó Mallorca, solar sobre el que se edificó la basílica donde se venera a la patrona de la ciudad y el Convento de la Merced que, tras la desamortización de 1836, pasó a ser la Capitanía General de Barcelona:

En 1234 se había construido en este emplazamiento un «Hospital de cautivos», dedicado a Santa Eulalia, la patrona de la ciudad, que funcionaba como casa de caridad y hospicio para cautivos liberados, con Nolasco como su comendador. Otras dos casas se habían fundado por entonces en Palma de Mallorca (en 1232) y Gerona (en 1234), y a partir de entonces la orden empezó a expansionarse a lo largo del litoral mediterráneo de Francia y España.

Todos estos planteamientos nos permiten intuir que la fundación de la orden se produjo en los años anteriores a la aprobación del papa Gregorio IX de 1235 y la relación del rey con Nolasco en los prolegómenos de las conquistas de Mallorca y Valencia. Nolasco, por su labor como exea o comerciante y redentor de cautivos, era conocedor de las tierras a conquistar y, por tanto, un personaje clave para un ejército de conquista.

La vinculación de la Merced con los sucesores del monarca aragonés fue más intensa, y en sus escritos queda reflejada la relación de la corona aragonesa

6. Este guarismo por sí solo resulta curioso, pues aunque los documentos referidos comienzan en fecha de 1238, refutan en parte las teorías aquellos historiadores, fundamentalmente no mercedarios, que basan la crítica a la fundación histórica del rey Jaime I en los escasos documentos que le relacionan con la orden.

7. Juan Devesa Blanco: «Documentos del rey Jaime I relativos a la orden de la Merced», en Actas de la XI Asamblea de Cronistas del Reino de Valencia, Valencia, 1978 p. 56. En este estudio, Devesa complementa los trabajos iniciados por Gazulla en 1909 que presenta documentos y diplomas de Jaime I, registrados en el A. C. A. relacionados con la Merced con fechas entre 1238-1276.

8. Faustino Gazulla: «Don Jaime de Aragón y la orden de Nuestra Señora de la Merced», en Memorias del I Congreso de Historia de la Corona de Aragón, Barcelona, 1909, p. 13.

9. Robert I. Burns: The Crusader Kingdom of Valencia, 2 vols., Cambridge, Massachusets, 1967. (Traducción castellana El Reino de Valencia en el siglo XIII, Valencia, 1985, p. 183). 
con la orden. Así lo manifiestan los escritos del reinado de Jaime II el Justo (1291-1327):

Existen noventa y nueve documentos durante su reinado referentes a la Merced. Preciosos e importantes por las noticias que dan sobre los orígenes de la orden, y por el amor que el rey muestra a la Merced fundada por su abuelo, de la que blasona ser patrono. ${ }^{10}$

Siendo importantes los documentos históricos y su estudio crítico, la imagen devocional del rey Jaime I se construyó desde las crónicas y las imágenes. Es por esto que en el presente artículo nos centraremos en las fuentes literarias y en las obras de arte que conformaron la imagen devocional del rey.

\section{EL ORIGEN DE LAS HAGIOGRAFÍAS}

Los franceses tenían un rey santo; Bonifacio VIII había canonizado a san Luis en 1297. La casa de Austria, defensora del orbe católico, quería refrendar esta empresa con el ejemplo de santidad de alguno de sus antepasados (fig. 2). Felipe IV se embarcó en el proyecto de canonizar a un rey de su estirpe, pues Dios legitima a los reyes de España y les garantiza gloria y grandeza. ${ }^{11}$ El rey de España tenía la obligación de patrocinar con especial fervor las ceremonias eclesiásticas, entre otras razones porque no disfrutaba del carácter sagrado de los taumaturgos reyes franceses e ingleses. El providencialismo cristiano y la defensa de la causa católica proporcionaron a la España de los Austrias su razón de ser. ${ }^{12} \mathrm{El}$ propio Felipe IV declaraba cuánto le interesaba al reino ver a uno de sus reyes en el catálogo de los santos, requisito que le faltaba a la grandeza de la monarquía.

La corona apostó por dos candidatos coetáneos a san Luis, adalides de la conquista cristiana, Jaime I y Fernando III. ${ }^{13}$ Después de valorar sus méritos de santidad, el camino más directo para su beatitud estuvo marcado por el decreto de Imaginibus y la fórmula del culto inmemorial, Jaime I presentaba entre otros méritos ser, según las crónicas, fundador de la Orden de la Merced e impulsor así mismo de la Orden del Císter en cuyo habito quiso ser enterrado.

10. JUAN DeVeSA BLANCO: «Documentos del rey Jaime I relativos a la orden de la Merced...», 1978, p. 60.

11. Víctor Mínguez: «De Dios y los reyes hispanos en la edad Moderna», en Víctor Mínguez (ed.): Visiones de la Monarquía Hispánica, Publicacions Universitat Jaume I, Castelló de la Plana, 2007, p. 14.

12. John Elliot: España y su mundo 1500-1700, Madrid, 1990, pp. 181-84.

13. Sobre la canonización de san Fernando cabe destacar los trabajos de FERnANdo Quiles: «En los cimientos de la Iglesia sevillana: Fernando III Rey y Santo», Boletín del Instituto Camón Aznar, LXXV-LXXVI, Zaragoza, 1999, pp. 203-249. Lourdes Amigo VÁzQuez: «La apoteosis de la Monarquía Católica Hispánica. Fiestas por la canonización de San Fernando en Valladolid (1671)», en ARANDA PÉREZ, FrANCISCO JOSÉ: La declinación de la monarquía hispánica en el siglo XVII, Ed. Universidad Castilla La Mancha, Cuenca, 2004, pp. 189-207. Alfredo J. Morales: «Rey y santo. Ceremonial por Fernando III en la Catedral de Sevilla», en Víctor Mínguez (ed), Visiones de la Monarquía Hispánica, Publicacions Universitat Jaume I, Castelló de la Plana, 2007, pp. 89-120 e InMACUladA Rodríguez: «Los Reyes Santos», en Víctor Mínguez (ed.): Visiones de la monarquía hispánica, Publicacions Universitat Jaume I, Castelló de la Plana. 2007, pp. 133-170. 


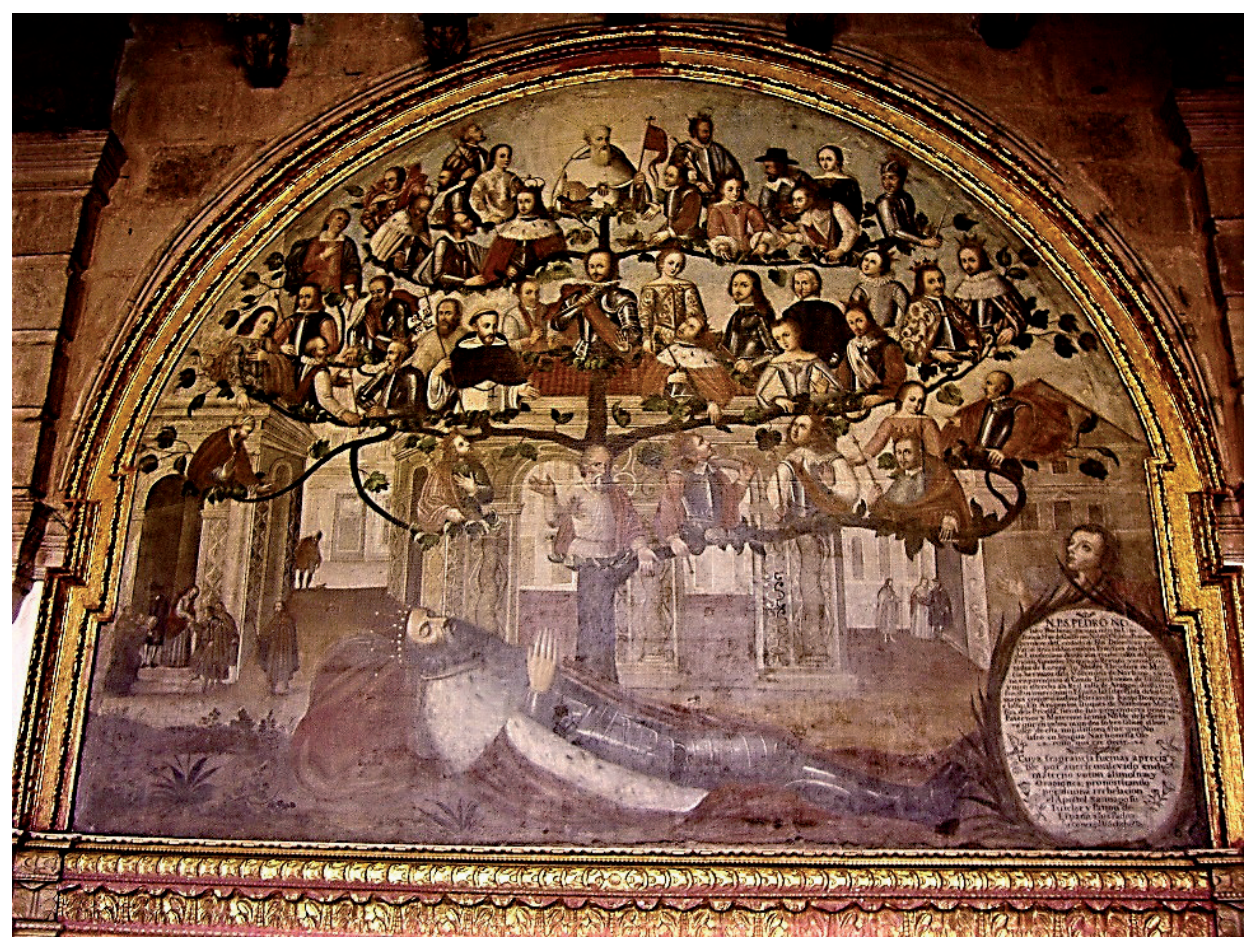

Fig. 2. Basilio Santa Cruz, Linajes y santidad en la casa real de Aragón, siglo XVIII, Claustro de la Merced de Cuzco, Perú

En 1633 se presenta ante la Santa Sede su proceso de canonización, ${ }^{14}$ pero tras los decretos urbanianos de 1635, los postuladores de la corona española ante la Santa Sede valoraron las dificultades que ponían estos decretos a la fórmula del culto inmemorial por la que se pretendía canonizar a Jaime I. Finalmente, su proceso fue descartado entre otros muchos motivos por su excomunión, levantada en 1237 por la intercesión ante el papa de san Raimundo de Peñafort, y centraron sus esfuerzos en la canonización de san Fernando III, quien tras un lento proceso fue elevado a los altares en 1671 durante el reinado de Carlos II.

La beatitud inmemorial de Jaime I fue narrada en las crónicas. El propio rey, al redactar el Llibre dels feits, se esforzó en transmitir una imagen de honesto, justo, valiente y guerrero, conquistador para la cristiandad de los reinos de Mallorca, Valencia y Murcia y de una devoción religiosa bien probada. ${ }^{15}$

14. Charles De Tourtoulon: Don Jaime I el Conquistador, rey de Aragón, conde de Barcelona, señor de Montpeller: según las crónicas y documentos inéditos, Imp. José Domenech, 1874, Valencia, vol. II, p. 414-415.

15. ViCENT. J. EsCARTí: «Jaume I, el Llibre dels feits i l'humanisme: un model “valencià” per al cesarisme hispànic», eHumanista/IVITRA 1, Ed. University of California, Santa Barbara, 2012, pp. 128-140. 
En su crónica escrita en 1335, Ramón Muntaner lo presenta como sanctus rex. Afirma que conoció al rey en su infancia cuando Jaime I se hospedó en la casa de sus padres en Peralada. El interés de Muntaner por Jaime I reside tanto en las hazañas del periodo de las conquistas, como en el hecho de que de Jaime I surgen las ramas esplendorosas del Reino de Aragón que llevarán a cabo la expansión mediterránea. ${ }^{16}$

Es aquí de donde parte su mitificación, que no es solamente física sino también espiritual. Para Muntaner, Jaime I ha sido un milagro de Dios y, como tal, lo describe en el capítulo III de su crónica, «e com lo naixement del senyor En Jaume fo per miracle, assenyaladament de Deus e per obra sua».

Muntaner, después de loar la participación del rey en el concilio ecuménico de Lion, en Francia, narrará sus últimos días en el capítulo xxviı de su crónica y describirá el tránsito al cielo del monarca tras recibir los santos sacramentos. Su afirmación «Lànima se partí del seu cors e sen'anà al Paraís» será suficiente para que Muntaner presuma su santidad: «E axi es ma fe, que ell es ab los sants en Parays: e aço ne deuen cascuns entendre».

El relato de Muntaner servirá a partir del siglo XIV para cimentar su fama de santidad. Por ejemplo, el 27 de julio de 1372 la ciudad de Valencia decretó que se celebrara el aniversario del «Molt excel.lent, sant e virituos rei en Jacme». ${ }^{17}$

La Crónica de san Juan de la Peña, ${ }^{18}$ escrita en aragonés en 1342 y atribuida al secretario del rey Pedro IV de Aragón, Tomás de Canellas, incide en el capítulo XXXV en la santidad de Jaime I indicando que era ayudado por «muitos santos del parayso» y relata la presencia de san Jorge junto al rey conquistador en la batalla del Puig de Santa María.

Et se trobó que muytos santos de parayso non tan solament ayudauan á éll quando hauía batallas con los moros, mas encara ayudauan á sus vassallos quando por él se combatian con moros. Porque se dice que como éll hauies enuiado algunos nobles et caualleros en el regno de Valencia ys assaber el noble Don Bernat Guillem Dentença, y de otros caualleros de Aragon et de Cataluña et fuessen en vn pueyo qui agora es clamado Santa Maria del Puig, y toda la morisma vinies contra ellos en la batalla qui entrellos fué muyt grant, los apareció San Jorje, con muytos caualleros de parada que los ayudó á vencer la batalla. Por la qual ayuda ningun xpistiano no hi murió.

16. Ernest Belenguer: Jaume I a través de la Història, 2. ${ }^{\text {a }}$ ed., Puv, Valencia, 2009, p. 40

17. Robert I, Burns: «The Spiritual Life of Jaume I the Conqueror, King of Arago-Catalonia, 12081276 Portrait and Self-Portrait», en Jaime I y su época, Ed. Institución Fernando el Católico, Zaragoza, 1979 , vol. 2, pp. 323-357, nota 6.

18. Tomás Ximénez De Embún Y Val: Historia de la Corona de Aragón, Imprenta del Hospicio, Zaragoza, 1876. Edición del manuscrito de Tomas de Canellas de 1342, conocida generalmente con el nombre de Crónica de san Juan de la Peña, en Biblioteca Virtual Joan Lluís Vives. Edición digital a partir de la edición de Tomás Ximénez de Embún, 2004, Capítulo xxxv, p. 158. https://cutt.ly/De3fMWN (consultada el 15 de octubre de 2018). 
El autor de esta crónica vincula de nuevo a san Jorge con los reyes de Aragón. En el capítulo XVIII relata que, en 1096, los cristianos vencieron en la batalla de Alcoraz y conquistaron Huesca gracias a la oportuna aparición de san Jorge, pieza clave de la victoria de Pedro I. Tras la lucha, los vencedores encontraron en el campo de batalla las cabezas decapitadas de cuatro reyes moros. Estos prodigios motivaron la incorporación de estas cuatro cabezas al sello real en el reinado de Pedro III en año 1281 y, como recuerdo de dicha batalla junto a la cruz de san Jorge, también conocida como cruz de Alcoraz, figuran en el escudo de Aragón.

En 1417, el Consell de la ciudad de Valencia encargó un manuscrito sobre la conquista de Valencia ${ }^{19} \mathrm{y}$, ocho años más tarde, el mestre racional pagaba a Leonard Crespí la iluminación de un códice de Les cróniques del rei en Jacme en latín para Alfons el Magnánim. ${ }^{20}$

Les cróniques d'Espanya, de Pere Miquel y Carbonell, ${ }^{21}$ escritas entre 1495 y 1513 y publicadas por primera vez en 1547, añadirán trascendencia al relato hagiográfico de Jaime I, situando a san Jorge y san Antonio luchando junto al rey en la conquista de Menorca. Finalmente será Pere Antoni Beurter ${ }^{22}$ en su Crónica general quien relate de manera más extensa los hechos milagrosos en torno a la batalla del Puig; en donde añade al relato de san Jorge luchando junto al rey el prodigioso hallazgo de la imagen de la Virgen del Puig, y retoma la fama de santidad del rey afirmando el anterior relato de Muntaner: «Las maravillas que en su nacimiento y criança acontecieron [...] olian y sabían a milagros».

La fama de santidad, anterior al inicio del proceso de canonización de 1633, será reforzada en el imaginario popular por comedias, como la de Francisco Agustín de Tárrega, La fundación de la Orden de la Merced por el rey don Jaime, ${ }^{23}$ escrita a finales del siglo Xvi y de manera fundamental por los escritos y crónicas mercedarias desde el siglo XV al XVII y su representación en grabados y pinturas de la orden en la época de las canonizaciones mercedarias.

De la comedia del segorbino Francisco Agustín Tárrega, ${ }^{24}$ publicada en 1608 seis años después de su muerte, cabe pensar que fue escrita en la última

19. Amadeo Serra: «En torno a Jaime I: de la Imagen al mito en el arte de la corona de Aragón en la baja edad media», en Victor Mínguez (de): Visiones de la monarquia hispánica, Publicacions Universitat Jaume I, Castelló de la Plana, 2007, p. 337

20. Francesca Español Beltrán: «El Salterio y libro de las horas de Alfonso el Magnánimo y el cardenal Joan Casanova», Locus Amoenus, 2002-2003, n. ํ 6, p. 105

21. Pere Miquel y Carbonell: Cròniques d'Espanya, Barcelona, 1547, Fol. 85 ro.

22. Pedro A. Beuter: Crónica General, Valencia, 1551, cap. xxxiI.

23. Portada de La fundacion de la Orden de Nuestra Señora de la Merced por el rey don Iayme / del canonigo Tarrega. Reproducción digital a partir de Norte de la poesía española: illustrado del sol de Doze comedias (que forman segunda parte) de laureados poetas valencianos, y de doze escogidas loas y otras rimas a varios sugetos, impreso en Valencia. Impresor Felipe Mey, a costa de Filipo Pincinali, 1616. Biblioteca Nacional (España). Sig. U/10337 https://cutt.ly/Ae3gola (consultada el 20 de octubre de 2018).

24. Francisco Agustín Tárrega fue uno de los fundadores de la Academia de los Nocturnos, grupo de literatos y dramaturgos entre los que se encontraban Gaspar Aguilar o Guillem de Castro. 
década del siglo XVI, pues el escritor parece conocer la obra de Felipe Guimerá Breve historia de la Orden de la Merced publicada en Valencia en 1591. En el texto destaca la labor del rey como fundador de la orden, pero con licencias literarias contrarias a la tradición mercedaria de los siglos XV y XVI. Sitúa la fundación de la Orden de la Merced en los años de la conquista de Valencia. Tárrega describe en las primeras escenas cómo la Virgen revela al rey la fundación de la Orden de la Merced, la llamada del rey a Nolasco para iniciar la labor redentora y las peripecias de este, pues entre otras situaciones el argumento de la comedia nos relata la conversión de Armengol, el capitán de bandoleros, tras su encuentro con Nolasco, lo que la motiva, y su ingreso en la recién fundada Orden de la Merced. ${ }^{25}$

En la primera jornada, segunda escena, aparece el rey Jaime con el limosnero y despensero, que se encuentran junto a él anotando las cuentas y gastos del día, se acerca la medianoche y cuando salen los dos lacayos, el rey saca un libro especial en el que anota las cuentas que tiene con la Virgen María, según dice don Jaime:

Vos sabéis, Reina sagrada, / que de todas mis victorias / os rinde parias mi espada, / y que os dan todas mis glorias / lo mejor cada jornada. / Y que del pobre caudal / de cualquier vencimiento, / Madre, Virgen celestial, / os doy al repartimiento / la parte del general.

En ese momento, Tárrega relata la aparición de la Virgen al rey, a quien llama a fundar la Orden de la Merced con un escapulario en la mano y, a su lado, se encuentran san Juan Bautista (sin duda licencia del autor), con el manto de su religión con cruz blanca; San Benito, con otras dos cruces (de Calatrava y de Alcántara); san Jorge armado con la cruz de Montesa, y Santiago con su insignia. El rey se arrodilla sobrecogido de temor religioso y oye a María que le dice:

Jaime, tus cuentas obligan / que te den cuenta del cielo; / allá mira tu buen celo, / tus intentos se prosigan. / Muy bien has administrado / mi hacienda; yo estoy contenta, / firmada está ya tu cuenta / ya Dios le dejó un traslado. / Una santa religión / has de fundar en mi nombre, / que porque redima al hombre / se ha de llamar Redención. / La Virgen de las Mercedes se dirá esta religión; mira si con tal blasón / estimar sus hijos puedes. / Cuyo ejercicio ha de ser / redimir cristianos míos, / y de redentores píos / el renombre han de tener. / El mundo en ellos verá / lo que en tenerlos granjea, / pues yo les doy mi librea / y Dios su nombre les da. / De Diego, Juan y Benito, / y de Jorge acompañada. / de sus cruces rodeada / que son de honor sobrescrito, / vengo a darte aquesta mía, / que en tu cuello has de poner, / porque Maestre has de ser / desta ilustre compañía, / cuyos soldados harás / en Barcelona muy presto. 
El rey está en la campaña de Valencia y, siguiendo las indicaciones de la visión, regresa a Barcelona a fundar la orden al tiempo que ordena a Lamberto, capitán de los almogávares, que emprenda una campaña contra los bandoleros del reino. En la escena siguiente, Tárrega nos presenta a Armengol como jefe de los bandoleros que le preparan una emboscada a Nolasco y Raimundo de Peñafort, que van camino de Barcelona al encuentro del rey a contarle la extraña aparición que han tenido y que Nolasco describe con estas palabras: «Digo que una Religión / he de fundar a su intento /que se llame Redención, / y que ha de ser del convento / amparo el Rey de Aragón.»

En el argumento de la comedia, a pesar de la sencillez, encontramos, no obstante, elementos que conformarán un discurso iconográfico importantísimo para la causa de beatificación del Jaime I que sitúan al rey como único fundador de la Merced treinta años antes del inicio de su proceso comenzado por Felipe IV para canonizar a un rey de su linaje.

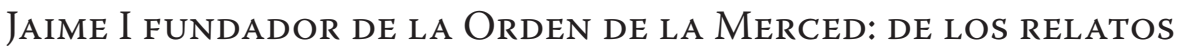 \\ A LAS IMÁGENES}

Los primeros escritos que relatan la fundación de la Orden de la Merced por parte de san Pedro Nolasco, el rey Jaime I y san Raimundo de Peñafort son el Speculum fratrum de Nadal Gaver, escrito en 1445 y publicado en 1533, y el Opusculum tantumm quinque, de Pedro Cijar, escrito en 1446 y publicado en 1491. Estos textos, fiados en la tradición oral y escritos doscientos años después de la fundación, serán las fuentes que inspirarán las obras de los siglos posteriores.

En la edición impresa de Speculum fratrum de Nadal Gaver de 1533, encontramos el primer grabado que sitúa al rey Jaime I bajo el manto de la Virgen de la Merced, que conforma el tipo iconográfico de Merced como misericordia. Sigue el esquema formal representado en la clave de la Catedral de Barcelona datada en 1381. Esta imagen devocional será difundida de manera masiva en la tradición iconográfica mercedaria desde el siglo XVI. Tirso de Molina, en su Historia general de la Orden de la Merced concreta el origen de la advocación de la Merced como misericordia, y sitúa su origen en la ceremonia de fundación celebrada el día de san Lorenzo de 1218. En la ceremonia según Tirso:

Cantose el evangelio y después de él, subiéndose en el púlpito, hizo el eloquentíssimo Raymundo un sermón todo apostólico, refiriendo la merced misericordiosa, que Diós y su Virgen y Madre se dignaban a hacer al mundo todo, y en particular a nuestra España, fundándoles una orden que se intitulasse con entrambos apellidos de Merced y Misericordia. 
García Gutiérrez ${ }^{26}$ en su estudio sobre la iconografía mercedaria, presentó este tipo iconográfico con la Virgen de la Merced como misericordia amparando bajo su manto a Nolasco y al rey Jaime I como fundadores, y al papa Gregorio IX como autor de la aprobación canónica. De entre todas las misericordias con el rey Jaime I a los pies de la Virgen cabe destacar la Apoteosis de la Merced, obra de Juan de Roelas pintada en el primer cuarto del siglo XviI procedente del convento de la Merced de Sevilla, y que en la actualidad se encuentra en la sacristía catedral de esta ciudad. La imagen nos muestra a la Virgen y, bajo su manto, buscan amparo las ramas masculina y femenina, el papa Gregorio IX, los reyes de Castilla y Aragón con las reinas, así como un grupo de cautivos. Buenos ejemplos de esta tipología serian la Merced como Misericordia con Gregorio IX y Jaime I (fig. 3), que se encuentra en la Curia General Mercedaria de Roma y tuvo su continuidad en los conventos mercedarios americanos en los siglos XVII y XVIII; así como la del convento de San Francisco de Potosí, en Bolivia o el lienzo de Francisco Lerma Villegas Virgen de la Merced como Misericordia con Gregorio IX y Jaime I que se conserva en el Museo de Arte Colonial de Caracas.

Si atendemos a los relatos y crónicas de los siglos XVI y XVVII, sus autores fundamentan la tradición histórica de la fundación de la orden por parte del monarca, la vida de Pedro Nolasco y los acontecimientos fundacionales del siglo XIII en antiguos escritos 0 «fuentes vetustas ${ }^{27}$ de autores que no son otros que los que acabamos de citar: Nadal Gaver y Pedro Cijar.

Un buen ejemplo de este tipo de referencias lo encontramos incluso en fuentes no mercedarias como los Anales de la Corona de Aragón, de Jerónimo Zurita, ${ }^{28}$ para narrar los sucesos del año 1218.

1218. Institución de la orden de la Merced con industria de Pedro Nolasco francés. En este año, según algunos autores escriben, tuvo principio la orden de Nuestra Señora de la Merced que fue una muy santa institución para la redención de los cautivos cristianos que están en poder de infieles. Y afirman haber dado favor el rey a una tan santa obra como esta por la devoción e industria de un notable varón natural de Francia llamado Pedro Nolasco.

Dentro de la Orden de la Merced encontramos autores que hacen suya la tradición del siglo xv, algunos sin citar las fuentes, como es el caso de Gaspar

26. Pedro García Gutiérrez: «Iconografía Mercedaria, Nolasco y su obra», en Revista Estudios, Madrid, 1985, p. 25.

27. Faustino Gazulla: La orden de Nuestra Señora de la Merced, Estudios Histórico Críticos (12181317). En dos volúmenes, el primer volumen vio la luz en Barcelona, en el año 1934. Los dos tomos en un solo volumen editados por el P. Juan Devesa se publicaron en Valencia en 1985, p. 43.

28. Jerónimo Zurita: Anales de la Corona de Aragón, 1562. Edición preparada por Ángel Cañellas López, Institución Fernando el Católico (CSIC), Zaragoza, 1967, p. 372. 
de Torres $^{29}$ quien en la introducción a las Constituciones de 1565, aumenta el relato del siglo $\mathrm{xv}$ haciendo hincapié en el papel de Jaime I como cofundador. Sin embargo, otros autores mercedarios fían sus estudios a la cita de sus fuentes. Un ejemplo claro lo encontramos en la obra de Felipe Guimerán. ${ }^{30}$

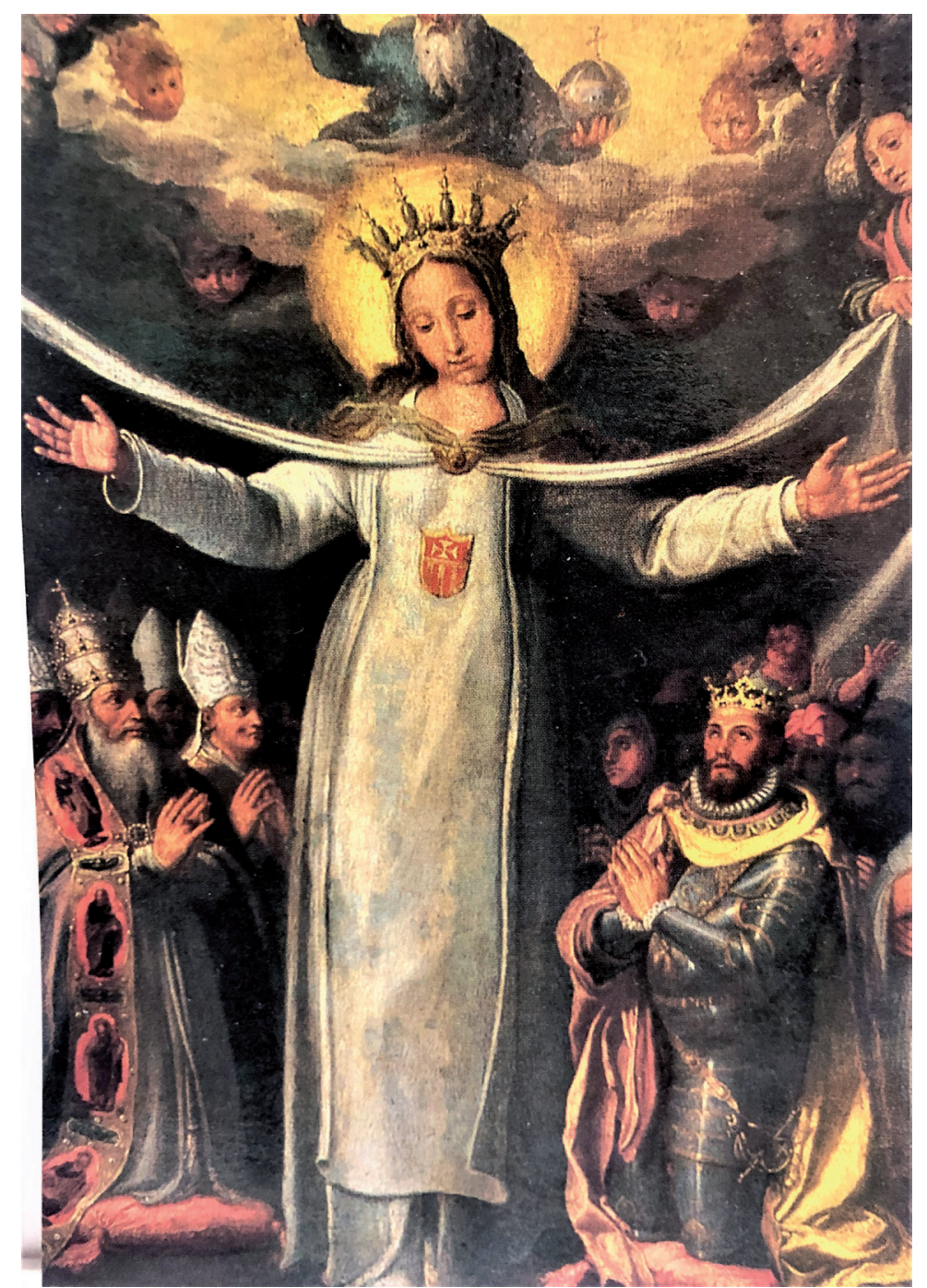

Fig. 3. Anónimo, Merced como misericordia, siglo xvII, Curia General Mercedaria de Roma

29. Gaspar De Torres: Regula et constitutionis sacri Ordinis Beatae Mariae de Mercede redemptoris captivorum, Salamanca, 1565, p. 8. Este libro supuso el primer intento de reforma de la orden siguiendo las indicaciones del rey Felipe II tras el concilio de Trento.

30. Felipe Guimeran: Breve Historia de la Orden de Nuestra Señora de la Merced, Valencia, 1591, p. 12. 
Y viniendo a mi propósito, empeño mi palabra al lector que cuanto en esta obra escribo, he investigado, y buscado la verdad sin perdonar trabajo. [...] Y quanto a lo que toca a nuestro Rey Don Jayme, y otras personas seculares de quienes hago mención en mi libro, entre los ordinarios escritores que todos leemos he seguido más a Gerónimo Çurita, acompañado de los comentarios del rey Don Jayme, que por mi gusto los tengo bien andados, en la fundación de nuestra bendita orden y las personas della, sigo a quatro principales escritores nuestros, que son el Reverendísimo fray Nadal Gaver, decimoctavo general nuestro, en los Anales de nuestra religión en que escribe las vidas de diecisiete maestros generales sus predecesores, con otros insidentes de aquellos tiempos. Otro es Fray Pedro de Cijar en un libro doctísimo en un libro que escribió de la excelencia de nuestro quarto voto. Heme ayudado también de lo que escribe el reverendíssimo Gaspar de Torres en el libro primero de las instituciones de nuestra orden, y últimamente de la historia de los padres de nuestra orden escrito elegantísimo del padre Maestro Francisco Çumel, cuyo nombre a vuelta de otras obras, y de su raro ingenio tiene vistas con singular satisfacción y aplauso el mundo; le lleva la fama volando por boca de todos, y de antiguas memorias que en algunos archivos nuestros he visto, que han servido no poco para todo quanto aquí escribo de nuestros frayles. Lo qual, y con quanto más tiene este libro lo sujeto a la correccion de la Santa Yglesia Romana Madre nuestra y de qualquier docto que pudiere darla.

La beatificación, en 1542, y posterior canonización, en 1601, del dominico san Raimundo de Peñafort, ${ }^{31}$ cofundador de la Merced junto al rey, motivó a los mercedarios a reivindicar la milagrosa fundación de la orden, el papel de Nolasco y del rey Jaime I como fundadores, las glorias de Nolasco y las heroicas vidas de sus mártires. Los relatos del siglo xvi de Torres, Zumel ${ }^{32}$ y Guimerán exaltaran estos hechos.

En el siglo XVII, los maestros generales de la orden ${ }^{33}$ se embarcarán en la empresa de remozar sus conventos contratando a los mejores pintores y grabadores que añadirán a los relatos las imágenes necesarias para las canonizaciones de sus santos mediante la fórmula del culto inmemorial. Uno de los primeros programas iconográficos en donde se vincula a Jaime I con la Orden de la Merced lo encontramos en el encargo que Fray Juan Bernal hace en 1600 a los pintores Alonso Vázquez y Francisco Pacheco para decorar el convento de la Merced Calzada de Sevilla con escenas de la vida de Pedro Nolasco.

En el cuadro de Alonso Vázquez, San Pedro Nolasco despidiéndose de Jaime I el Conquistador, se nos muestra la caridad y generosidad del rey con la labor redentora de la orden por él fundada. El rey se despide de Nolasco, que parte a tierras de moros a rescatar cautivos cristianos, en el Palacio Real de Barcelona

31. San Raimundo de Peñafort será beatificado en 1542 por Pablo III y canonizado en 1601 por Clemente VIII.

32. Francisco Zumel: Vitis Patrum, Opúsculo final del libro Regula et constitutiones fratrum sacri ordinis beatae Mariae de Merced redemptionis captivatum, Salamanca, 1588.

33. En estos procesos, tras el generalato de Zumel, trabajarán conjuntamente las provincias de Aragón y Castilla, así como las ramas calzada y descalza de la orden. 
y le entrega una gran cantidad de dinero para los rescates que es portada por cuatro hombres. De ello dan cuenta tanto el escribano que anota la donación, como el mercedario y el niño que porta los libros de cuentas y rescates presentes en todos los conventos mercedarios.

Asimismo, en 1610, Fray Isidro de Valcázar encarga al grabador del rey, Pedro Perret, ${ }^{34}$ el grabado de la Institoris navis, (fig. 4) un resumido tratado de dogmática tridentina donde el rey Jaime I adquiere protagonismo como fundador. El lema del grabado «Institoris navis servitutum omnium liberatrix» (Prov.: 31,14), según indica la cita, procede del Libro de los proverbios. ${ }^{35} \mathrm{La}$ nave del mercader que sirve «para liberar de toda esclavitud». Metáfora que nos presenta a la orden de la Merced al servicio de la Iglesia y el papado, este representado por el papa Gregorio IX quien, el 17 de enero de 1235, concedió la bula aprobatoria de la orden. ${ }^{36}$

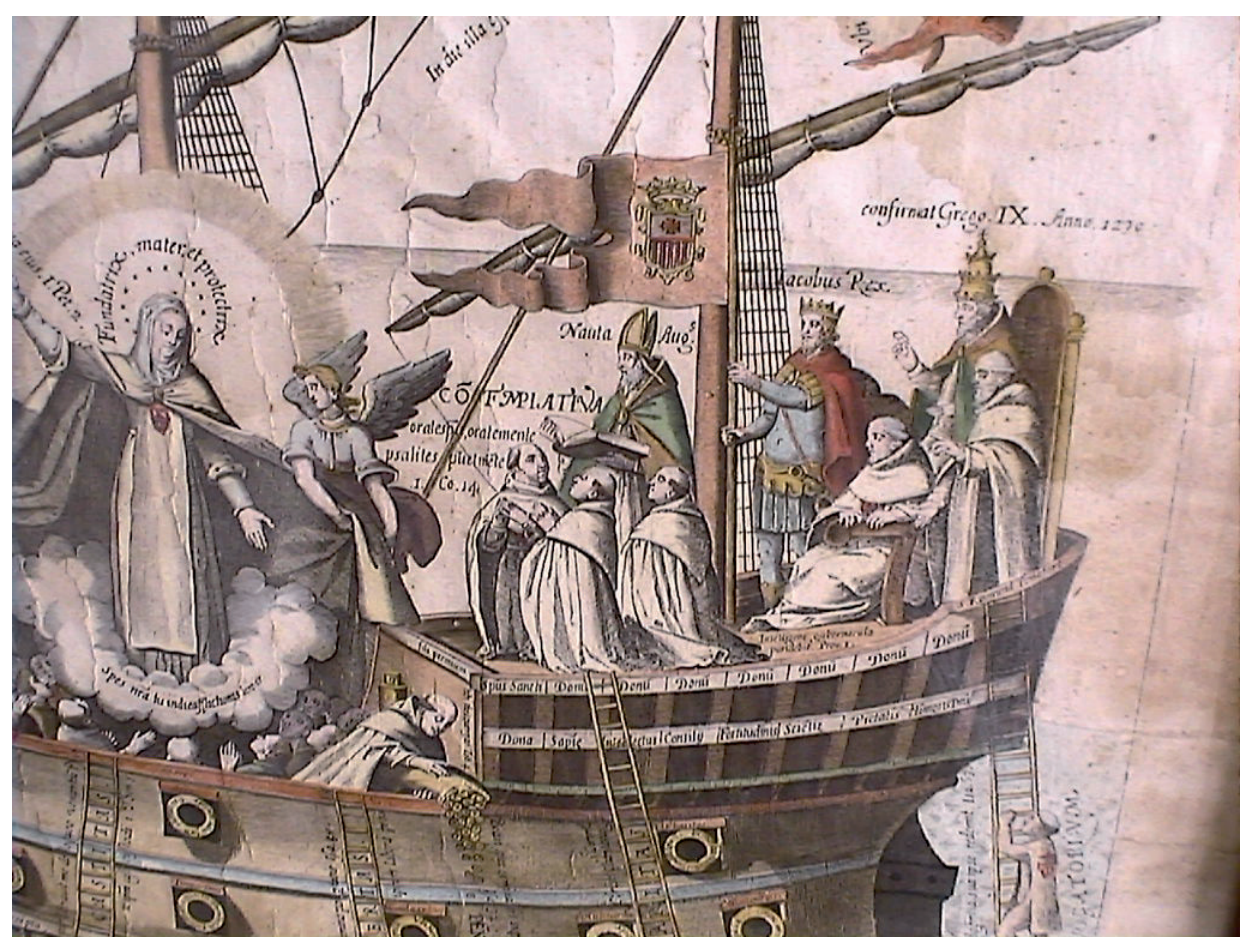

Fig. 4. Pedro Perret, grabado de la Institoris navis de la orden de la Merced, 1610. Detalle de la toldilla.

34. Vicent F. Zuriaga Senent: «La Institoris navis de P. Perret en la formación de la imagen de la Merced», en A. Bernat Vistariniy J. T. Cull (ed.): Los días del Alción, Barcelona, 2002, p. 617.

35. Este capítulo del Libro de los proverbios narra de manera alegórica las virtudes de la mujer fuerte. El padre Valcazar, autor del texto que aparece en el grabado, se concede una licencia literaria cambiando el final del versículo original «Facta et quasi navis institoris, de longue portans panem suum».

36. El grabado ilustrando la fecha de confirmación, 1230, sobre la tiara del Papa Gregorio IX, presenta un error cronológico, pues la bula fue fechada el 17 de enero de 1235 . 
Desde la toldilla, el pontífice gobierna la nave sentado en la cathedra acompañado por san Agustín, bajo el título de nauta, a cuya regla se someten los mercedarios como consecuencia de la bula aprobatoria. Junto a estos, se encuentran los tres cofundadores de la Merced que participaron en la fundación, pues según la tradición mercedaria, tuvieron la misma visión la noche del 1 de agosto de 1218 y estuvieron presentes en la ceremonia del 10 de agosto del mismo año en la capilla real de Barcelona; a saber: el rey Jaime I, que porta el estandarte con el escudo de la de la orden, otorgado por él mismo a la orden según los relatos de Nadal Gaver y Gaspar de Torres; acompañados por el tercer cofundador, san Raimundo de Peñafort ya canonizado, y Pedro Nolasco que comanda el timón de la nave y dirige su rumbo bajo el lema «Inteligens gubernacula posidebit», ('El inteligente adquirirá destreza'). Aún no se le ha canonizado, pero el grabador Pedro Perret, siguiendo las indicaciones de fray Isidro de Valcázar, marca al timonel con el título de beato, dando fama de santidad a Nolasco, afirmando de manera implícita su culto inmemorial.

Las crónicas de Remón ${ }^{37}$ y Vargas ${ }^{38}$ ampliarán el relato fundacional de los autores del siglo Xvi Gaver, Cijar, Torres, Zumel y Guimerán y fundamentarán el relato de la de la milagrosa fundación de la Orden de la Merced, con la aparición de la Virgen a Jaime I, Nolasco y Raimundo de Peñafort.

El capítulo general mercedario de 1622, a instancias del maestro general Gaspar Prieto, acordó iniciar los trabajos de postulación de la causa de canonización de san Pedro Nolasco. ${ }^{39}$ El padre Alfonso de Molina ${ }^{40}$ procurador del proceso y autor del texto de postulación o Memorial de canonización que obtuvo el nihil reperio en 1623, facilitó los textos de las veinticinco escenas descritas en el octavo cuadernillo. Los dibujos de estas fueron encargados al pintor aragonés Jusepe Martínez en el mes de junio de 1622 y los grabados fueron estampados en Roma en 1627 por el grabador Federico Greuter. Para la difusión posterior de los grabados se encargó a Cornelio Cobrador una segunda serie copiada al trasluz de la de Jusepe Martínez con textos en castellano.

Del total de veinticinco grabados presentados en el proceso, en la actualidad solo se conservan diez, y coinciden con los textos del octavo cuadernillo. Este hecho nos permite afirmar que la serie dibujada por Jusepe Martínez, se tomó como referente en algunos casos y en otros como modelo directo para las series pictóricas encargadas en los conventos mercedarios en los siglos XVII y XVIII.

37. Alonso Remón: Historia General de la Orden de la Merced, Tomo I, Madrid, 1618. Tomo II, Madrid, 1620.

38. Bernardo De VArgas: Chronica sacri et militia ordinis B. Mariae de Mercede redemptionis captivotum, Tomo I, 1619, Palermo. Tomo II, 1622, Palermo. Vargas, un año más tarde publicará en Salamanca la Vida de san Pedro Nolasco escrita en castellano a diferencia de la Chronica, escrita en latín.

39. J. M. Delgado Varela: «La canonización de san Pedro Nolasco», Estudios, Madrid, 1956, año XII, n. ${ }^{\circ} 35-36$.

40. Alfonso De Molina: Memorial, Historia di San Pietro Nolasco, Roma, 1623. 
La apuesta de los mercedarios por difundir las glorias de la orden, hizo que desde 1628 se pintaran en muchos de sus conventos los ciclos de la vida de san Pedro Nolasco siguiendo los modelos de Jusepe Martínez y las escenas narradas en el Memorial, ${ }^{41}$ uniendo a la fama de santidad de Nolasco la participación del rey Jaime como fundador y mentor de la orden. El paso del tiempo, las guerras y la desamortización disgregaron muchas de estas series, como ocurrió con los veintidós cuadros de la serie que pintó Francisco de Zurbarán, entre 1628 y 1634, para el claustro de los Bojes del convento de la Merced de Sevilla, de la que únicamente se conservan diez cuadros dispersos en distintos museos del mundo. Sin embargo, una de las series más interesantes por su dependencia de los grabados de la canonización ha permanecido unida y, en la actualidad, se puede visitar en el Museo de BBAA de Córdoba. La pintó Francisco Cobo de Guzmán en los primeros años del siglo XVIII. ${ }^{42}$ Mayor fortuna han tenido las series que podemos contemplar en los conventos americanos. Los mejores ejemplos los encontramos en los lunetos del convento de la Merced de Cuzco, obra de Basilio Santa Cruz y Espinosa de los Monteros, así como los pintados por Juan Jayo para la iglesia de la Merced de Lima, o los pintados por Francisco Albán para el convento de la Merced de Quito.

El Rey Jaime I protagoniza dos de las escenas del Memorial. La primera se corresponde con la Estampa vi: San Pedro Nolasco recibe el hábito de manos de la Virgen y describe la visión de los tres cofundadores:

Estampa vi. Lema: «Suadeo tibi emere a me aurum probatum et vestimentas albis induaris». ${ }^{43}$ Apoc. 3.

Epigrama o suscriptio: «Sacrato die Vinculis Sancti Petri anno domini 1218 virum dei iubet per visum Beata virgo ut Ordinem Redemptoris Captivorum Instituta; idem etiam ipsa noce Sancto Raymundo (de Peñaforte) et Jacobo Regi Aragón monstratum est. Cemens (in Bullis Canonizationis ${ }^{44}$ Sancti Raimundi)». ${ }^{45}$

41. M. E. Manrique ArA: «La Historia di San Pietro Nolasco del pintor Jusepe Martínez», en Analecta Mercedaria, Roma, 1996, pp. 73-115.

42. María Teresa Ruiz Barrera: «Programas iconográficos de la Merced en Andalucía: Semblanzas barrocas», en M. A Rodríguez Miranda (coord.): Nuevas perspectivas sobre el barroco andaluz. Tradición, arte, ornato y símbolo, Ed. Asociación para la investigación de la historia del arte y del patrimonio Cultural "Hurtado Izquierdo", Córdoba, 2015, p. 817.

43. «Te aconsejo que compres el oro probado y te vistas con vestiduras blancas» (Apc. 3, 18)

44. No es inocente la mención, Alfonso de Molina podía haber citado la escena siguiendo los escritos mercedarios, pero cita la escena de la bula de Canonización de San Raimundo, porque entre otros méritos fue canonizado por fundar la Orden de la Merced. Era lógico, en un escrito para la canonización de Nolasco, que se argumentara por el contrario que, si a san Raimundo de Peñafort la bula papal lo canoniza por haber fundado la Orden de la Merced, cuánto más motivo que por esto mismo se canonice a san Pedro Nolasco.

45. Traducción del padre Juan Devesa. «Sagrado día de 1218 en que en que el santo varón Pedro por la visión de la Virgen se instituyó la orden de Redentores de Cautivos. Eso mismo vieron san Raimundo de Peñafort y el rey Jaime I de Aragón (según la bula de Canonización de San Raimundo)». 
Descripción de la imagen: La beata Virgen se aparece al santo y le da el hábito de la orden, y este lo recibe arrodillado. A lo lejos, aparecen un rey en el lecho y san Raymundo, de la orden de Santo Domingo, en oración, y ambos ven la misma revelación.

En 1634, un año después de que se inicie el proceso de canonización del rey Jaime I, el convento de la Merced de Murcia encarga las pinturas del retablo mayor del convento a Cristóbal de Acebedo. El cuadro central del retablo (fig. 5) La aparición de la Virgen de la Merced a Jaime I y san Pedro Nolasco presenta una singularidad que lo hace único, pues nos muestra al rey como fundador de la orden y protagonista de los sucesos de la noche del 1 de agosto de 1218. Los mercedarios con este encargo se unen al esfuerzo de la corona en vincular al rey en la fundación de la Merced. El rey Jaime I se nos muestra en un primer plano en la escena de la revelación de la Virgen al rey para que funde la Orden de la Merced, institución que dedicará a redimir y rescatar a los cautivos cristianos en manos de los moros, al tiempo que recibe de esta el escapulario mercedario.

La composición de este cuadro está inspirada en la escena vi del Memorial de canonización de Nolasco, pero presenta la variante fundamental que le da originalidad al postergar a san Pedro Nolasco, que ya había sido canonizado en 1628, a un segundo plano contemplando la misma visión. El cuadro nos presenta un nuevo tipo iconográfico en la iconografía mercedaria, y solo se entiende por el inicio del proceso de canonización del rey en 1633 mediante la fórmula del culto inmemorial, en donde la veneración de las imágenes era motivo suficiente para la elevación del santo a los altares. Los decretos urbanianos de 1635, que exigían a las pinturas un siglo de antigüedad para que pudieran ser incorporadas al proceso, justifican la singularidad y la originalidad de la imagen del convento de Murcia en el contexto de la canonización de Jaime I.

Jaime I es protagonista también en la escena viI del texto del Memorial, escena de la que no conservamos el grabado de Jusepe Martínez, pero de la que tenemos abundantes ejemplos tanto en las series españolas como en las americanas. Además de la referencia a Nadal Gaver, cita también como fuente la Breve historia de la Orden de la Merced de Felipe Guimerá, que fue el obispo de Jaca a quien hace referencia como tal en la cita.

\section{Escena VII.}

Lema: «Homo Quem rex honorarie voluerit debet indui vestibus regis». (Ester $6,7-8)$

Epigrama o subscriptio: «S. Raymundus barcinonensibus divinam revelationem exponit. Rex Iacobus, slemni ritu militari, Ordinem redemptions instituit, ac S. Petrum Nolascum, primum eius Magistrum Regium. Regio Aragonum insigni, addita ad Episcopo cruce suae Ecclesiae, cohonestat. Natalis Gaver, in Hist. Ord. Et ep de Jaca)» 


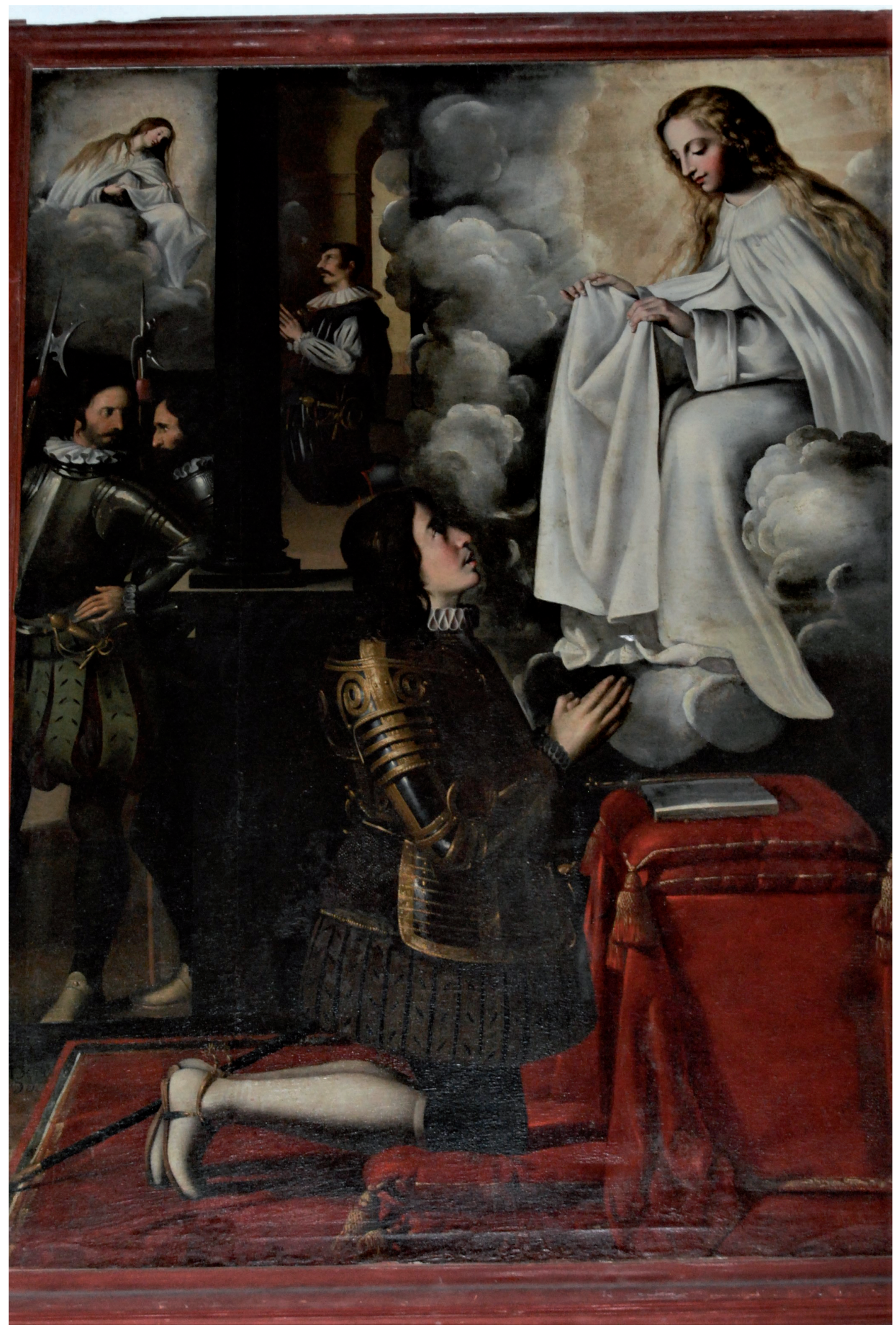

Fig. 5. Cristóbal de Acebedo, La aparición de la Virgen de la Merced a Jaime I y san Pedro Nolasco, 1634, Iglesia de la Merced de Murcia. 
La descripción de la imagen: San Raimundo sobre el púlpito predicando. El rey da al santo las armas de Aragón. El obispo le da la Cruz, que lleva sobre las armas. El santo con algunos compañeros vestidos de gentilhombres, son recibidos cantando Te Deum laudamus.

Destaca, entre todas las representaciones, la que preside el altar de la Virgen de la Merced de la Catedral de Barcelona, un relieve escultórico (fig. 6) policromo en talla de madera obra del escultor catalán Joan Roig que data de 1688. La escena, por su parecido a la representada por Cobo de Guzmán para la Merced de Córdoba, nos permite intuir el grabado de Jusepe Martínez como modelo de la composición.

En la segunda mitad del siglo XVIII Vergara, en sus trabajos para la Merced en Valencia, reproduce esta escena en un lienzo de gran tamaño. Cuadro que en la actualidad aún se puede contemplar en el claustro alto del monasterio del Puig de Santa María (fig. 1). Vergara también representó este tipo iconográfico en uno de los lunetos procedentes del antiguo convento de la Merced de Valencia. ${ }^{46}$ Las series americanas seguirán con fidelidad los textos sobre la fundación, así como los grabados del Memorial que sin duda llegaron a estos conventos.

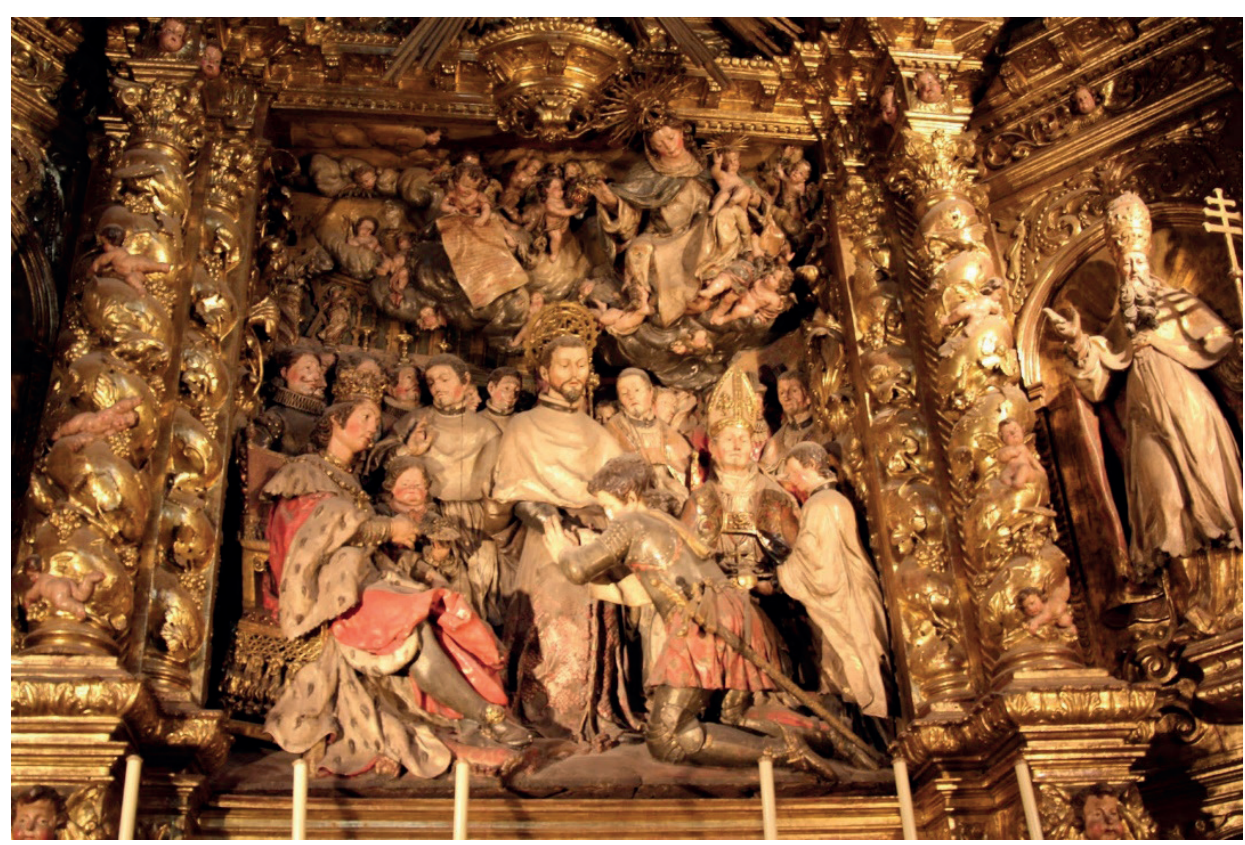

Fig. 6. Joan Roig, Fundación de la Orden de la Merced el 10 de agosto de 1218, 1688, Capilla de la Merced, catedral de Barcelona.

46. Otra serie de diez lunetos que seguía el relato del Memorial la pinto José Vergara en el siglo XVIII para el convento de la Merced de Valencia y hasta hace seis años, por cesión del Ministerio de Cultura, estaba expuesta en la sacristía vieja del Monasterio del Puig de Santa María. En 2013 fue trasladada a los depósitos del Museo de Bellas Artes de Valencia. 
JAIME I Y SUS IMÁGENES DE SANTIDAD: LA LEYENDA DE SAN JORGE,

la batalla del Puig, el hallazgo de la Virgen del Puig y

LAS PROFECÍAS DE LA CONQUISTA DE VALENCIA

Jaime I promovió en el Llibre dels feits la creación de su retrato de la fama, los cronistas de la corte de Aragón y los escritores corrigieron y aumentaron este relato hasta convertirlo en hagiográfico en los siglos XIV al XVI. Ya en el siglo XIV, algunos retablos góticos, inspirados en estos relatos, convertirán en devocional la imagen del rey vinculada a san Jorge, de manera singular en los sucesos relacionados con la Batalla del Puig, los prodigios del hallazgo de la imagen de la Virgen del Puig y las profecías de la conquista de Valencia.

El retablo del Puig de mediados del siglo XIV, destruido en 1936, era una buena muestra de la que sin duda podemos encontrar imágenes similares en otros retablos. El retablo de Jérica de mediados del siglo xiv obra de Berenguer Mateu, presenta la singularidad de que fue pintado poco después de la narración de Tomás de Canellas en la Crónica de san Juan de la Peña en el reinado de Pere el Cermoniós, la representación coincide con el relato, al igual que ocurre con el retablo posterior más conocido como Retaule del Centenar de la Ploma, pintado en el tránsito de los siglos XIV al Xv, que en la actualidad se conserva en el Victoria \& Albert Museum de Londres. El retablo posiblemente fue pintado para la capilla que la cofradía de ballesteros que el Centenar de la Ploma tenía en la iglesia de San Jorge de la ciudad de Valencia, y allí permaneció hasta su demolición.

El mismo tipo iconográfico inspirado en la narración de la Crónica de san Juan de la Peña lo encontramos en la tabla central del retablo de san Jorge de la iglesia de la Merced de Teruel San Jorge y Jaime I en la batalla del Puig, procedente de la iglesia de San Miguel, obra de Gerónimo Martínez, datada en 1525.

Estas tablas presentan la característica común de formar parte de retablos devocionales que destacan la virtud y valentía del rey que, ataviado con las armas de Aragón, lucha en la batalla del Puig contra los sarracenos acompañado por san Jorge.

La crónica de Antonio Beuter, ${ }^{47}$ en 1551, ampliará el relato de la batalla del Puig con los prodigios del hallazgo de la Virgen del Puig y las profecías de la conquista de Valencia. Su relato quedará reflejado en exvotos, como el pintado en el $A l m u d i^{48}$ de Valencia, en los gozos de mediados del siglo xvi y en las series pictóricas del siglo XVII.

La iconografía postridentina impulsada desde la Orden de la Merced seguirá el relato ampliado de Felipe Guimeran, las crónicas de Remón y el libro de

47. Pedro. A. Beuter: Crónica General, Valencia, 1551. (Ed. Fascimil, Valencia, 1995), 2. ${ }^{\circ}$ Libro, caps. $\mathrm{xxx}$ al XxxiI.

48. El Almudi de Valencia era el antiguo granero de la ciudad, en la actualidad es una sala de exposiciones del Ayuntamiento. 
Francisco Boíl ${ }^{49}$ Nuestra Señora del Puche escrito en 1631, dos años antes del inicio de del proceso de canonización de Jaime I y que presenta un relato hagiográfico de rey en los prodigios de la conquista de Valencia. En estos textos se narra el hallazgo de la imagen de la Virgen del Puig por parte del rey Jaime I.

Las representaciones más importantes que refieren el Hallazgo de la Virgen del Puig y Las profecías de la conquista de Valencia, son las de Jusepe Martínez para el memorial de canonización de Zurbarán, Espinosa, Pontons, Cobo de Guzman, Basilio Santa Cruz, Juan Jayo Francisco Albán y Vergara.

El cuadro de Zurbarán, que en la actualidad se encuentra en EE. UU. en el Museo de Cincinnati, formaba parte del encargo hecho al pintor tras la canonización para la serie de la Merced Calzada de Sevilla (1629-1634), encargada a Zurbarán por Fray Juan de Herrera, para el claustro de los Bojes.

El cuadro interpreta en lienzo los textos de Beuter y Guimerán. En el texto de Beuter no se nombra a san Pedro Nolasco pero sí al hallazgo de la Virgen bajo la campana por parte del rey Jaime I, mientras que el texto de Guimerá relata la aparición en el cielo de siete estrellas con la presencia de San Pedro Nolasco junto al rey sobre la colina actual del monasterio.

Ambos relatos nos indican que, después de haber conquistado el castillo de Cebolla (El Puig de Santa María) y cuando está preparando la batalla para conquistar Valencia, el rey interpreta como prodigiosa la aparición de siete luceros sobre la colina situada frente al castillo y ordena excavar, hallando una campana bajo la cual se encontraba oculta la Virgen del Puig. Zurbarán nos muestra el momento de la invención de la imagen, con las figuras del rey Jaime I, Guillem d'Entença y a dos mercedarios, uno de ellos se supone que es san Pedro Nolasco.

El lienzo de Espinosa es más complejo, datado en 1660, pudo contar como fuente de inspiración con los textos de Beuter y Guimerá, además de con el texto de Boíl. ${ }^{50}$ La complejidad viene dada por la visión mística de Cristo que expresa Espinosa para tratar el tema. Es Cristo quien muestra con la mano derecha, de la que salen siete luceros, el hallazgo de la campana con la imagen de la Virgen, mientras que con la izquierda señala en la parte superior la visión de una ciudad. En esta ciudad se puede ver la Jerusalén celeste, y la profecía de la conquista de Valencia, ya que es el perfil de esta ciudad el que aparece representado en la parte superior. Ambas visiones nos son relatadas por Tirso. ${ }^{51}$ Nolasco le indica al rey que los prodigios del hallazgo de la imagen son señal del cielo que asegura la pronta conquista de la ciudad. Tras la conquista el rey entregará las llaves de la ciudad a la Virgen y la proclamará patrona del reino.

49. Boíl Francisco: Nuestra Señora del Puche, Cámara angelical de María Santíssima. Patrona Angelical de la insigne ciudad y Reino de Valencia. Monasterio Real del Orden de redentores de Nuestra Señora de la Merced. Fundación de los reyes de Aragón, Valencia, 1631.

50. Francisco Boíl: Nuestra Señora del Puche, Cámara angelical de María Santíssima. Patrona Angelical de la insigne ciudad y Reino de Valencia. Monasterio Real del Orden de redentores de Nuestra Señora de la Merced. Fundación de los reyes de Aragón, Valencia, 1631.

51. Tirso de Molina: La Virgen del Puig, Valencia, 1638, pp. 32-33. Un año más tarde, Tirso, en su Crónica escrita en 1639, cita el texto de Boíl y dedicará dos capítulos: «La profecía de la conquista de Valencia», p. 56. y «Visión de la Jerusalén celeste», p. 62. 
El cuadro San Pedro Nolasco profetiza la conquista de Valencia, de Pablo Pontons (fig. 7) representa al rey y a san Pedro Nolasco en el castillo del Puig desde el que Nolasco le recuerda la profecía que le hizo al rey y la pronta conquista de la ciudad de Valencia que aparece dibujada a lo lejos. En el texto, Pontons nos indica que la profecía de la conquista se produjo diez años antes de la batalla del Puig, por lo que la imagen representada se nos presenta como concepto de lo que expresa la profecía.

De mediados del siglo xviII, es la reforma del camarín de la Virgen de la iglesia del Puig, que se articula bajo una cúpula sobre pechinas, las pinturas del camarín las ejecutará al fresco José Vergara. Los frescos de la cúpula narran en imágenes la historia del hallazgo de la imagen de la Virgen del Puig. Siguiendo los textos de Boíl, dos escenas muestran como los monjes basilios ocultan la imagen tras la conquista musulmana, mientras que en el lado opuesto representa el hallazgo de la imagen por parte de san Pedro Nolasco y el rey Jaime I. Los frescos de las pechinas muestran la imagen esculpida por los ángeles, cómo ante ella rezan san Pedro y san Pablo, y cómo es traslada por los ángeles y venerada por basilios y mercedarios. Los tondos de los laterales muestran en la imagen la rendición de Valencia con Zayyan rindiendo la ciudad a Jaime I y al rey entregando las llaves de la ciudad a la imagen de la Virgen del Puig. Estas mismas representaciones de la leyenda de san Jorge, la batalla del Puig, el hallazgo de la Virgen del Puig y las profecías de la conquista de Valencia las encontraremos en las series americanas siendo de especial interés las de los conventos de Lima, Cuzco y Quito.

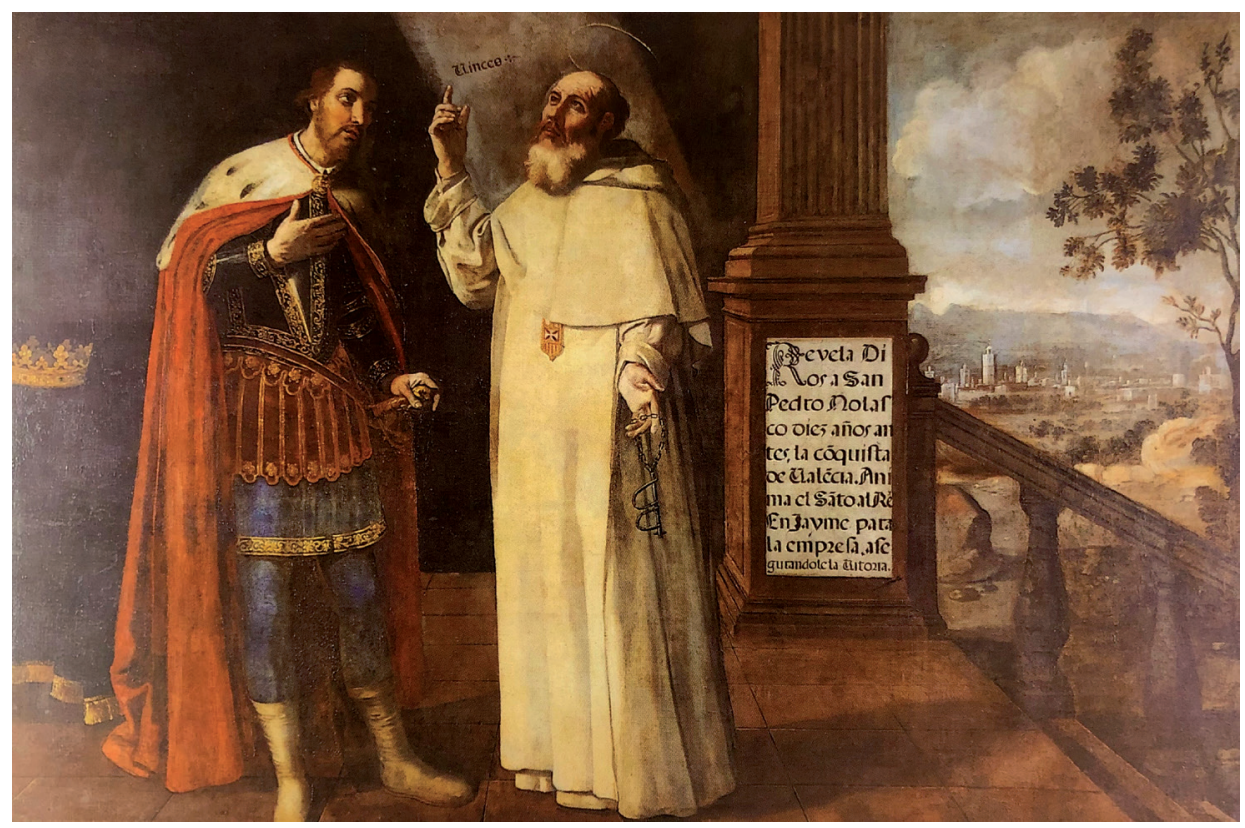

Fig. 7. Pablo Pontons, San Pedro Nolasco profetiza la conquista de Valencia, siglo XVII, Ayuntamiento de Valencia. 


\section{Conclusión}

La construcción de la imagen devocional del rey Jaime I, si bien tiene su origen en el retrato de la fama que de Jaime I relatan las crónicas, se consolida paulatinamente en los escritos y obras de arte de los siglos XIV al XVIII. La apoteosis de su imagen como rey fundador se impulsa tanto por el interés mutuo de la Orden de la Merced por vincular su origen fundacional con la monarquía como desde la casa de los Austrias por elevar a los altares a un rey de su linaje. Los postuladores del proceso de canonización de Jaime I tenían un primer fundamento para iniciar su causa: la fundación de la Orden de la Merced y los prodigios y milagros en los que participaba el monarca recogidos por las crónicas y las obras de arte; a esto añadieron los testimonios de virtudes cristianas que adornaban al monarca y sumaron las imágenes anteriores al inicio de la causa que permitían promover su culto inmemorial. En este contexto, se justifica la producción de las imágenes anteriores al inicio del proceso en 1633. Los decretos urbanianos de 1634 que exigían para la canonización la conocida como centuria urbaniana, es decir, que las imágenes tuvieran una antigüedad anterior a cien años, supusieron un grave contratiempo para la canonización del rey mediante esta fórmula y, finalmente, por este y otros muchos motivos no prosperó. Sin embargo, por parte de la Merced continuó la construcción del relato y la representación de este en imágenes a lo largo de los siglos XVII y xviII tanto en los conventos en la península como en los territorios de ultramar.

\section{Bibliografía}

Amigo VÁzquez, L.: «La apoteosis de la Monarquía Católica Hispánica. Fiestas por la canonización de San Fernando en Valladolid (1671)», en Francisco José Aranda PÉrez: La declinación de la monarquía hispánica en el siglo XVII, Ed. Universidad Castilla La Mancha, Cuenca, 2004.

Belenguer, Ernest: Jaume I a través de la Història, 2. a ed., puv, Valencia, 2009, p. 40.

Beuter, Pedro. A.: Crónica General, Valencia, 1551, cap. xxxiI.

Boíl, Francisco: Nuestra Señora del Puche, Cámara angelical de María Santíssima. Patrona Angelical de la insigne ciudad y Reino de Valencia. Monasterio Real del Orden de redentores de Nuestra Señora de la Merced. Fundación de los reyes de Aragón, Valencia, 1631.

Bordman, James W.: «New Perspectives on the Creation of the Mercedarian Order», en

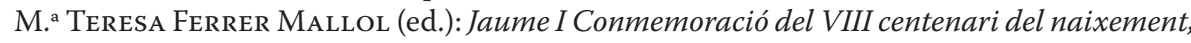
Institut d'estudis Catalans, Barcelona, 2013, vol. II.

-: Ransoming captives in Crusader Spain: The Order of Merced on the ChristianIslamic Frontier, Filadelfia, 1986. Traducción catalana, Barcelona, 1990.

Burns Robert I.: The Crusader Kingdom of Valencia, Cambridge, Massachusets, 1967, vol. 2. Traducción castellana El Reino de Valencia en el siglo XIII, Valencia, 1985.

-: «The Spiritual Life of Jaume I the Conqueror, King of Arago-Catalonia, 1208-1276 Portrait and Self-Portrait», en Jaime I y su época, Ed. Institución Fernando el Católico, Zaragoza, 1979, vol. 2. 
Cijar, Pedro: Opusculum tantum quinque, 1446. Manuscrito, llevado a imprenta en Barcelona en 1491.

Delgado Varela, J. M.: «La canonización de San Pedro Nolasco», en Estudios, Madrid, 1956, año XII, n. ${ }^{\circ} 35-36$.

Devesa Blanco, Juan: «Documentos del rey Jaime I relativos a la orden de la Merced», en Actas de la XI Asamblea de Cronistas del Reino de Valencia, Valencia, 1978.

Dilla Martí, Ramón: Sant Ramon de Penyafort. Imatge, devoció i santedat. Tesis doctoral publicada por la Universitat de Barcelona, 2017, p. 26. https://cutt.ly/ce3g0dh (consultada el 17 de julio de 2019).

Elliot, John: España y su mundo 1500-1700, Madrid, 1990.

EsCartí, Vicent. J.: «Jaume I, el Llibre dels feits i l'humanisme: un model "valencià" per al cesarisme hispànic», en eHumanista/IVITRA 1, Ed. University of California, Santa Barbara, 2012.

Español Beltrán, Francesca: «El Salterio y libro de las horas de Alfonso el Magnánimo y el cardenal Joan Casanova», Locus Amoenus, Publicacions Universitat Autónoma de Barcelona, 2002-2003, n. ${ }^{\circ} 6$.

García Gutiérrez, Pedro: «Iconografía Mercedaria, Nolasco y su obra», en Estudios, Madrid, 1985.

Gazulla, Faustino: «Don Jaime de Aragón y la Orden de Nuestra Señora de la Merced», en Memorias del I Congreso de Historia de la Corona de Aragón, Barcelona, 1909, p. 13.

-: La orden de Nuestra Señora de la Merced, Estudios Histórico Críticos (1218-1317), Barcelona, 1934, vol. 1. Los dos tomos en un solo volumen editados por el P. Juan Devesa se publicaron en Valencia en 1985.

Guimeran, Felipe: Breve Historia de la Orden de Nuestra Señora de la Merced, Valencia, 1591.

Manrique Ara, M. E.: «La Historia di San Pietro Nolasco del pintor Jusepe Martínez», en Analecta Mercedaria, Roma, 1996.

Mínguez, Víctor: «De Dios y los reyes hispanos en la edad Moderna», en Víctor Mínguez (ed.): Visiones de la Monarquía Hispánica, Publicacions Universitat Jaume I, Castelló de la Plana, 2007.

Miquel y Carbonell, Pere: Cròniques d'Espanya, Barcelona, 1547. Fol. 85 ro.

Molina Alfonso De: Memorial, Historia di San Pietro Nolasco, Roma,1623.

Morales Alfredo J.: «Rey y Santo. Ceremonial por Fernando III en la catedral de Sevilla», en Víctor Mínguez (ed.): Visiones de la Monarquía Hispánica, Publicacions Universitat Jaume I, Castelló de la Plana, 2007.

Muntaner, Ramón: Chronica, o descripcio dels fets, e hazanyes del inclyt Rey don Jaume Primer. Manuscrito de 1325, Valencia, 1558. https://cutt.ly/9e3g9MC (consultada el 20 de octubre de 2018).

Quiles, Fernando: «En los cimientos de la Iglesia sevillana: Fernando III Rey y Santo», en Boletín del Instituto Camón Aznar, Zaragoza, 1999, LXXV-LXXVI.

Remón, Alonso: Historia General de la Orden de la Merced tomo i. Madrid, 1620, tomo II, cap. v, libro XI, p. $9 \mathrm{v}^{\circ}$

Rodríguez Moya, Inmaculada: «Los Reyes Santos», en Víctor Mínguez (ed.): Visiones de la Monarquía Hispánica, Publicacions Universitat Jaume I, Castelló de la Plana, 2007.

Ruiz Barrera, María Teresa: «Programas iconográficos de la Merced en Andalucía: Semblanzas barrocas», en M. A Rodríguez MiRANDA (coord.): Nuevas perspectivas sobre el barroco andaluz. Tradición, arte, ornato y símbolo, Ed. Asociación para la investigación de la historia del arte y del patrimonio Cultural "Hurtado Izquierdo", Córdoba, 2015.

Serra, Amadeo: «En torno a Jaime I: de la Imagen al mito en el arte de la corona de Aragón en la baja edad media», en Víctor Mínguez (ed.): Visiones de la Monarquía Hispánica, Publicacions Universitat Jaume I, Castelló de la Plana, 2007.

TÁRREga, Francisco: La fundacion de la Orden de Nuestra Señora de la Merced por el Rey don Iayme / del canonigo Tarrega. Reproducción digital a partir de Norte de la poesia española: illustrado del sol de Doze comedias (que forman segunda parte) de laureados poetas valen- 
cianos, y de doze escogidas loas y otras rimas a varios sugetos, Impresor Felipe Mey, a costa de Filipo Pincinali, Valencia, 1616. Biblioteca Nacional (España). Sig. U/10337 https://cutt. ly/Be3g3Ja (consultada el 20 de octubre de 2018).

TAYLOR, BRUCE: «La orden de la Merced en crisis: Un aspecto de la historia eclesiástica francocatalana de los siglos XVI-XVII», en Pedralbes, Revista d'Història Moderna, Actes del IV Congrés d'Història Modèrna de Catalunya, Barcelona, 1998.

Tirso De Molina: La Virgen Del Puig, Valencia,1638.

-: Historia general de la orden de Nuestra Señora de las Mercedes Manuscrito de 1639. Edición de Penedo Rey, Volumen I (1218-1567); Volumen iI (1567-1639) Madrid,1975.

Torres, Gaspar De: Regula et constitutionis sacri Ordinis Beatae Mariae de Mercede redemptoris captivorum. Salamanca, 1565.

Tourtoulon, Charles de: Don Jaime I el Conquistador, Rey de Aragón, Conde de Barcelona, Señor de Montpeller: según las crónicas y documentos inéditos. Imp. José Domenech, Valencia, 1874, vol. II.

VV. AA.: Les Quatre grans cròniques: Jaume I, Bernat Desclot, Ramon Muntaner i Pere III el Cerimoniòs, Ed. Selecta, Barcelona, 1971.

Vargas, Bernardo De: Chronica Sacri et Militia Ordinis B. Mariae de Mercede Redemptionis Captivotum, Tomo I, Palermo, 1619. Tomo II, Palermo, 1622.

-: Vida de san Pedro Nolasco, Salamanca, 1623.

Ximénez, De Embún y VAL, Tomás: Historia de la Corona de Aragón, Imprenta del Hospicio, Zaragoza, 1876. Edición del manuscrito de Tomas de Canellas de 1342, Conocida generalmente con el nombre de Crónica de San Juan de la Peña. En Biblioteca Virtual Joan Lluís Vives Edición digital a partir de la edición de Tomás Ximénez de Embún, 2004, cap. Xxxv, p. 158. https://cutt.ly/Je3g7Kg (consultada el 15 de octubre de 2018).

Zumel, Francisco: Vitis Patrum. Opúsculo final del libro Regula et constitutiones fratrum sacri ordinis beatae Mariae de Merced redemptionis captivatum Salamanca, 1588.

Zuriaga Senent, Vicent F.: «La Institoris navis de P. Perret en la formación de la imagen de la Merced», en A. Bernat Vistarini y J. T. Cull (ed.): Los días del Alción, Barcelona, 2002.

-: La imagen devocional en la Orden de Nuestra Señora de la Merced: tradición, formación, continuidad y variantes, Universitat de Valencia, 2005.

Zurita, Jerónimo: Anales de la Corona de Aragón, 1562. Edición preparada por Ángel Cañellas López, Institución Fernando el Católico (CSIC), Zaragoza, 1967. 